\title{
FAMILY EDUCATION; STRENGTH AMID THE DANGER OF INTOLERANCE
}

\author{
Ahmad Munirul Hakim \\ Lecturer at the State Islamic Institute (IAIN) Salatiga \\ Email: hakim94.iainsalatiga@gmail.com
}

\author{
Adkha Bukhori \\ Gadjah Mada University Students \\ Email: adkha.bukhori@mail.ugm.ac.id
}

\begin{abstract}
Conflicts between religions that lead to violence. The clashes between religious communities in Indonesia cannot go away and happen continuously. Family indifference is also a problem for building religious tolerance. This study aims to describe family education as a major force in overcoming the threat of intolerance and its implications. This research uses qualitative research methods. Data collection was carried out through interviews, documentation, literature study and online. For in-depth interviews, the informants consisted of seven people, namely academics, community organization leaders, Islamic studies researchers, and students. The data analysis technique used descriptive analysis, data presentation and drawing conclusions. The results showed that educational activities initiated by parents in the family need to be continuously encouraged to develop the importance of the spirit of unity. Parents can provide education about noble and positive values in social life. The danger of intolerance that increasingly threatens the integration of the nation, thus family education becomes a capital of strength in countering these worries. Overall family education has an important value in teaching children to have open insights in the midst of multicultural differences in society, religion and nationality.
\end{abstract}

Keywords: Family Education, Religious Tolerance, Intolerance.

Abstrak: Konflik antar agama yang berujung pada kekerasan. Benturan antar umat beragama di Indonesia tersebut tidak bisa hilang dan terjadi terus menerus. Sikap acuh tak. acuh keluarga juga menjadi masalah untuk membangun sikap toleransi agama. Penelitian ini bertujuan untuk mendeskripsikan pendidikan keluarga sebagai kekuatan besar dalam mengatasi ancaman bahaya intoleransi beserta implikasinya. Penelitian menggunakan metode 
IJIERM: Vol. 2 No. 2 May - July 2020

penelitian kualitatif. Pengumpulan data dilakukan melalui wawancara, dokumentasi, studi pustaka dan daring. Untuk wawancara mendalam, informan terdiri dari tujuh orang, yaitu akademisi, tokoh organisasi masyarakat, peneliti studi Islam, dan mahasiswa. Teknik analisis data menggunakan analisis deskriptif, penyajian data dan penarikan kesimpulan. Hasil penelitian menunjukean, kegiatan edukatif yang diprakarsai oleh orang tua di dalam keluarga perlu terus-menerus digalakkan untuk mnegmbangkan pentingnya spirit persatuan. Orangtua dapat memberikan pendidikan tentang nilai-nilai lubur dan positif dalam kebidupan bermasyarakat. Bahaya Intoleransi yang semakin mengancam integrasi bangsa, maka pendidikan keluarga menjadi modal kekuatan dalam menangkal kekbawatiran tersebut. Secara keseluruban pendidikan keluarga memiliki nilai penting untuk mengajarkan anak agar mempunyai wawasan yang terbuka di tengah perbedaan multikultural bermasyarakat, beragama dan berbangsa.

Kata Kunci: Pendidikan Keluarga, Toleransi Beragama, Intoleransi.

\section{Introduction}

Indonesia, as one of the countries with the highest multiculturalism in the world, actually facilitates the emergence of friction in various sectors, be it race, ethnicity or religion. The emergence of friction that is prone to occurring can certainly raise concerns that result in various kinds of conflicts in the community. People can be struck by dislike over differences in race, ethnicity and religion. In fact, clashes between communities can occur because of the wrong perspective of a person towards differences, in this case the clash due to conflict between religious communities is one of the problems that continues to occur.

If we look at the sociological-theological study, religion not only regulates the relationship between humans and their Gods, more than that religion also regulates the relationship between humans and other humans, even with their surroundings. ${ }^{1}$ Thus, the clashes in society caused by religion are not in accordance with the basic principles of diversity, namely hablum min al-nass, and can even be said to destroy sacred values in a religion.

Indeed, sociologists have concluded that from a social perspective, religion has two different faces. On the one hand, religion is able to foster social order

1 Ridwan Lubis, Sosiologi Agama; Memahami Perkembangan Agama dalam Interaksi Sosial, Jakarta: Prenadamedia Group, 2015, hlm. 86. 
(harmony), peace, social integration, meaning, and morality. However, on the other hand, a religion also creates wars and revolutions. ${ }^{2}$ Even so, clashes in society caused by religion should not be justified.

In its history, there have been many clashes between communities which have resulted in religious differences. For example, the conflict that occurred in Poso in early 1990 to 2000, the Sunni-Shiite conflict in Sampang, East Java in 2006, the conflict in Bogor related to the GKI Yasmin Development since 2000, and the conflict in Aceh in 2016. Again, Cases Ketapang which started from a fight between thugs and local residents, then continued to change the "SARA" conflict between the Ambonese Christian ethnicity and the Islamic Javanese ethnicity, starting with throwing at places of worship, mosques, then countermeasures in the form of burning shops and places of worship, churches are various cases of conflict related to conflict. religious differences.

Conflicts between religions that lead to violence at any time cannot be justified. The phenomenon that occurs implies that religion is not fully understood by its adherents. Religion, which is supposed to be a bridge of brotherhood for humans, in this case Indonesian society, has actually become a boomerang in itself which can lead to divisions. In this case, religion is used as a cover for conflicts of interest.

Therefore, if the clashes between religious communities in Indonesia cannot disappear and occur continuously, then this is worrying for the sustainability of diversity in Indonesia which has actually been protected by the 1945 Constitution. In the 1945 Constitution Article 29 paragraph 1 and 2 has clearly emphasized that the Indonesian state is very concerned and serious in granting the right to freedom of religion to all citizens.

If we look deeper, religion has actually transformed itself into a view that leads to two things. First, humanity. Second, citizenship. In the view of humanity, religion defines humans according to its teachings. This means that religion has taught humans not only regarding glory before God, but more than that the glory given to humans by religion has implications for the awareness of universal human solidarity, without any differences. ${ }^{3}$

2 Sri Yunanto, Islam Moderat vs Islam Radikal; Dinamika Politik Islam Kontemporer, Yogyakarta: Media Pressindo, 2018, hlm. 90.

3 Syaiful Arif, Islam, Pancasila, dan Deradikalisasi, Jakarta: PT Elex Media Komputindo, 2018, hlm. 106. 
IJIERM: Vol. 2 No. 2 May - July 2020

Whereas the second view of citizenship is placing all people equal before the law. In citizenship, a person cannot impose the views and interests of his / her religious group, because he is limited by state rules that are regulated by law. This means that citizens' rights to live in certain religious beliefs are strictly protected.

Prof. M. Quraish Shihab in his book al-Lubab once stated that followers of religions are like children who claim to be true to their father. In the end, it was Father who was the supreme judge. With this understanding, even though someone really believes in their religion they adhere to, there will be no more compulsion of opinions and much less forcing the truth on others. ${ }^{4}$

More than that, the Medina Charter which was a specific and modern law at that time also talked about one's independence in embracing religion. The recognition and existence of all religions cannot be denied that it really encourages the creation of harmony and harmony in life, because people have the freedom to practice the religions and beliefs they believe in. Moreover, in the context of Islam the prohibition against religious coercion has become a distant principle set out in QS. Al-Kafirun verse 7.

According to Ali Masrur, one of the problems in communication between religions today, especially in Indonesia, is the emergence of an attitude of lazy tolerance. This attitude arises as a result of patterns of indirect encounters between religions, especially regarding sensitive theological issues. Thus what happens is an attitude that can raise suspicion among several parties of different religions, which then triggers conflict in the name of religion. ${ }^{5}$ So that one of the ways that every religious community in Indonesia must do regarding religious problems is to create religious tolerance.

Simply put, tolerance can be understood as the attitude of an individual person or group by letting others get something according to their interests. This means that in the religious context, tolerance can be realized by respecting each other and protecting the rights of everyone to embrace a certain religion, so that what happens will always be conducive to carrying out their respective worship.

${ }^{4}$ M. Zainuddin dan M. In'am Esha (ed), Islam Moderat; Konsepsi, Interpretasi, dan Aksi, Malang: UIN-Maliki Press, 2016, hlm. 153.

5 Firdaus M. Yunus, Konflik Agama di Indonesia; Problem dan Solusi Perpecabannya, Jurnal Substantia, Volume 16 Nomor 2, Okotber 2014. 
According to Webster's New American Dictionary the meaning of tolerance is liberty to ward the opinions of others, patients with others (to give freedom to other people's opinions, and to be patient with others). Tolerance is defined as giving a place to different opinions. At the same time, respect for different opinions is accompanied by restraint or patience. ${ }^{6}$ So that it can be given an understanding that tolerance goes hand in hand with a willing attitude towards the different choices of others.

In messages related to tolerance, KH. Abdurrahman Wahid (Gus Dur) once said, "If you are hostile to people of a different religion than you, it means that what you believe in is religion, not Allah." Therefore, someone who has acknowledged that he is religious, then a tolerant attitude should appear in him towards the various beliefs held by other people.

Tolerance between religious communities is very necessary in maintaining harmony in social life consisting of different religious backgrounds. Without tolerance there can be no life together. Tolerance between religious communities is also a determinant of the harmony and harmony of community life where dynamic social relationships are created which involve the relationships of individuals and between community groups.

This attitude of tolerance in religion is important to be cultivated since childhood, from the smallest scope, namely the family. Family is the first field of education for teenagers and their education is the second. Parents play an important role in guiding and providing religious education, as institutions that interact with children. Gilbert Highes; states that the habits owned by children are largely formed by family education. From waking up until going back to sleep, children receive influence and education from the family environment. ${ }^{7}$ So that this can be used and used by parents to provide understanding to their children regarding the importance of tolerance.

\section{Method}

This research is a type of library research with a qualitative approach, namely research that does not compute quantitative data. ${ }^{8}$ Research is used to

\footnotetext{
${ }^{6}$ Firdaus M. Yunus, Konflik Agama di Indonesia; Problem dan Solusi Perpecahannya, Ibid.

${ }^{7}$ Fatmawati, Peran Keluarga Terhadap Pembentukan Kepribadian Islam Bagi Remaja, Jurnal RISALAH, Vol. 27, No. 1, Juni 2016.

${ }^{8}$ Lexy J. Moleong, Metode Penelitian Kualitatif, (Bandung: Remaja Rosda Karya, 1990),
} hlm. 2. 
IJIERM: Vol. 2 No. 2 May - July 2020

describe what it is about a variable, symptom, or situation in the field. ${ }^{9}$ The data collection method used is descriptive-interpretation. The data analysis used is qualitative with the process of compiling the data so that it can be interpreted.10 This method is used as a way of perceiving data that is appropriate and relevant to the subject matter of the discussion and describes the object of study, then interpreted as an effort to review the discussion of family education as a force in the midst of the danger of intolerance that often occurs in Indonesia which is known as a multicultural society so that these reviews can received and understood clearly.

The determination of informants was based on the research objectives. ${ }^{11}$ This aims to analyze the causes and factors of intolerance, as well as the impact of family education in preventing the dangers of intolerance. In total, all informants in this study were seven informants, consisting of: two academics, two Islamic studies researchers, two students, and one person from a religious-based community organization.

Data collection techniques obtained in this study from various sources, namely: in-depth interviews, documentation, and online. Then a selective selection of data was carried out and adjusted to the problems raised in the study. This research data analysis technique refers to the thematic analysis model with the descriptive ${ }^{12}$ approach proposed by Braun \& Clarke, a method for identifying, analyzing and reporting themes in the data.

\section{Discussion}

\section{Family Education Concept}

Etymologically, the family consists of two syllables, namely 'kawula' and 'residents'. Kawula means servant, while citizen means member. In a broad sense,

\footnotetext{
${ }^{9}$ Moh. Nazir, Metode Penelitian, (Bogor: Ghalia Indonesia, 2005), hlm.63.

10 Tatang M. Amirin, Menyusun Rencana Penelitian, (Jakarta: RajaGrafindo Persada, 1995), hlm. 134.

${ }^{11}$ J. W. Creswell, Research Desaign: Qualitative, Quantitative, and Mixed Methods Aprroaches 3rd Edition, (California: Sage Publication, 2014), hlm. 69.

12 V. Braun dan V. Clarke, Using Thematic Analysis in Psychology, Qualitative Research in Psychology, 2006), hlm. 36.
} 
a family is defined as a group of people who are related by blood or descent, ${ }^{13}$ that is, in simple terms, including mother, father, and children.

According to Ali Qaimi, the family is a social organization formed from the relationship between a man and a woman legally, which consists of husband, wife, and children and live together based on mutual love, love, tolerance, help, and cooperation. ${ }^{14}$ Therefore, someone who has gathered in a community called "family" must have an attitude of belonging to one another.

According to Syamsu Yusuf, family is the main determinant of children's personality formation. There are three things behind this, first is that the family is the first social group that becomes the center for identification of children. Second, a child will certainly spend a lot of time in his family environment. Third, all family members are "significant people" for a child's personality. ${ }^{15}$

Parents can provide guidance to children, so that they know their rights and obligations. ${ }^{16}$ This is indicated by Allah through His Word:

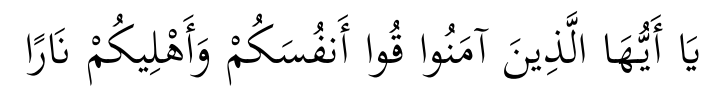

"O people who believe, guard yourself and your family from the fire of hell,.." (Surah At-Tabrim verse 6).

Family attention in protecting the family from religious behavior, both concerning worship and religion, is an important thing. Parents must be role models and role models for their children. Therefore, this attention must be able to be instilled from childhood.

The challenge of families in educating members to grow a sense of tolerance is the attitude of family members who may not yet know the importance of tolerance, the attitude of a family member who still has not accepted the attitude of tolerance between fellow humans. Parents who are too busy with their work, too focused on social media, and easily provoked are also serious obstacles. With that, the family must teach from an early age a good tolerant attitude in

13 J. Rahmat dan M. Gandaatmaja, Keluarga dan Masyarakat Modern, Bandung: Remaja Rosda Karya, 1989, hlm. 20.

14 Ali Qaimi, Menggapai Langit Masa Depan Anak, Bogor: Cahaya, 2002, hlm. 2.

15 Syamsu Yusuf, Psikologi Perkembangan Anak dan Remaja, Bandung: PT Remaja Rosda Karya, 2011, hlm. 37.

${ }^{16}$ Muh. Anis, Sukses Mendidik Anak: Perspektif Al-Qur'an dan Hadis, (Yogyakarta: Pustaka Insan Madani, 2009), hlm. 21. 
IJIERM: Vol. 2 No. 2 May - July 2020

society. Families must promote a soft approach to provide a tolerant understanding. Make everyone aware that differences are sunnatullah.

A child who is raised in a harmonious and religious family environment will certainly have a positive personality effect on the child. On the other hand, a child who grows up in a messy, disharmonious, even minimal understanding of religion will give a child's personality development which tends to be less good, even distorting himself.

In connection with that, sociologically M.I Sulaeman once gave the characteristics of family functions, namely first the family functions as education, second, the family functions as socialization. Third, the family functions as protection. Fourth, the family functions as an affection. Fifth, the family functions as religious. Sixth, the family functions as an economy. Seventh, the family functions as recreation. All eight families function as biological. ${ }^{17}$ Meanwhile, Imron explained, family education is the various efforts made by parents in the form of providing habituation and improvisation to help the development of the child's personality. ${ }^{18}$

Based on the above family functions, it is imperative that the importance of fostering good and positive children's personality souls. Through education, parents can provide education about noble and positive values in life. Through religion, parents can teach children about the importance of a relationship with God. Parents can provide direction to children on various things that are allowed and prohibited, including having good social relationships, good variety tolerance with others.

\section{The Dangers of Intolerance in Indonesia}

Tolerance between religious communities is an important part of that, which must continue. Like the multicultural society in Indonesia. The emergence of an awareness of tolerance will suppress and minimize any conflict with a religious background. In this case, tolerance is not only focused on respecting the theology and faith of other religious people, but more than that, understanding and respecting the culture of the religious community concerned.

There are two types of tolerance in religion that are important to understand, first is passive religious tolerance, which is the attitude of accepting

${ }_{17}$ M.I. Sulaeman, Pendidikan dalam Keluarga, Bandung: Alfabeta, 1994, hlm. 113.

${ }_{18}$ M. Imron Abdullah, Pendidikan Keluarga Bagi Anak, (Cirebon: Lektur, 2003), hlm. 232. 
all existing differences as factual. Second, active religious tolerance is not limited to accepting differences, but tolerance that involves oneself with others even in the midst of differences and diversity. ${ }^{19}$

Limited knowledge and a lack of desire to dig deeper into knowledge. The loss of respect for differences of opinion or not starting to study religion with a universal human understanding. Conservative and old-fashioned religious understanding. It all causes a person or group to act intolerant.

Muhammad Rafi'i in the interview said that the types of tolerance were marked by the closure of places of worship, the prohibition of loudspeakers of places of worship, and not accepting associating with different people. In addition, Aprizal Sulthan Rasyid as a researcher in Islamic studies categorizes three types of intolerance, namely intolerance of minorities, intolerance of different identities, and intolerance of differences in thought.

The results of the interview regarding the obstacles in preventing rampant intolerance in society are as follows:

"The obstacles faced are usually a matter of control of individuals both in the family and society. Social control is important in providing a tolerant influence in socializing in society. On the state side, the state should be present at every point that is considered vulnerable to intolerant acts. In addition, the state is obliged to provide guidance to the community to be more tolerant "(Imam Sumantri, Academician).

"Lack of self-awareness of the community to learn independently related to tolerance. Acuk is indifferent to the existing problems. Not all of them can respect the opinions or suggestions given" (M. Syarif Hidayatullah, Muhammadiyah Kota Batu).

"The large number of people who still do not know the important meaning of what tolerance is, and there are still many people who still cannot accept a difference, so it is difficult to determine tolerance within the country" (Brilian Oktarosa Ainurrachmah, Student).

It is hoped that the obstacles in preventing rampant intolerance in society can be started from oneself. Every individual should be able to be open minded

${ }^{19}$ Casram, Membangun Sikap Toleransi Beragama dalam Masyarakat Plural, Wawasan: Jurnal Ilmiah Agama dan Sosial Budaya 1, 2 (Juli 2016): 191. 
IJIERM: Vol. 2 No. 2 May - July 2020

to the differences that exist as sunnatullah. Intolerant behavior has spread massively both nationally and globally. Solutions to these national and global problems stem from actions taken by local communities, including families, RT / RW, schools, work environments, universities, and others.

When dealing with increasingly widespread intolerant behavior. Intolerant behavior can be countered with peaceful actions, actions that convey the message of the true meaning of pluralism in the spirit of unity. These peaceful actions can be in the form of actions that invite people to fight intolerance together, organize movement networks, demonstrate solidarity with victims of intolerance, and reject hate propaganda. This action can be done by everyone, if you want to end intolerant behavior, riots and hatred.

Tolerance is grown by an awareness that is free from all forms of pressure or influence and is protected from hypocrisis. Tolerance implies that it is possible to form a system that guarantees the safety of persons, property and minority elements in society. This can certainly be realized by respecting religion, morality and their institutions and respecting the opinions of others and the differences that exist in their environment without having to disagree with others just because of different beliefs or religions. Thus, family education needs to continually multiply peaceful activities, as well as peaceful campaigns.

In relation to religion, tolerance includes issues of belief in human beings related to faith or those related to God that they believe in. A person must be given the freedom to believe in and embrace any religion he chooses and to pay respect for the implementation of the teachings he holds or believes.

Tolerance between religious communities is a determinant of the harmony and harmony of community life in which dynamic social relationships are created which involve the relationship between individuals and between community groups. Religious tolerance is very necessary in social life, especially for a pluralistic society like the one in Indonesia. ${ }^{20}$ In general, intolerant behavior is born from rejection and fear, over a lack of understanding in dealing with differences in culture, nation, and religion. Massive efforts are needed in the campaign to prevent intolerance, both from the state, religious leaders, and the community. It is better if the doctrine of intolerance must be prevented and

20 Ika Fatmawati Faridah, Toleransi Antarumat Beragama Masyarakat Perumaban, Unnes: Jurnal Komunitas, 5 (1) (2013), hlm. 17. 
combated by socializing tolerance so that it can be maximized. This lack of understanding of religious tolerance leads individuals to be arrogant and exaggerate themselves or their groups. These ideas are taught and learned in childhood from the environment, be it school, family, or community.

Several efforts to prevent intolerant cases in Indonesia. Law enforcement and education about tolerance at various levels of education and society. Families and communities must be strengthened through diversity literacy and dialogue across identities and media crews who are able to advocate for serious cases of intolerance. From the family side, it is necessary to strengthen aqidah from an early age, form character and understanding of family members according to religious guidance. Meanwhile, from the state side, it is necessary to provide strict punishment for intolerant behavior, disseminate the importance of tolerance and implement curriculum in multiculturalism-based educational institutions in Indonesia.

\section{Implications of Family Education on the Threat of Intolerance}

Interactions that are so significant in the family are always important to emerge. This family interaction is one of the important things in shaping a person's personality. Good personalities in the form of morals, values, habits, and even character can be formed stronger in the family environment. Therefore, it is not only the parent's affection for a child, but the formation of a child's character is important to prioritize in order to have a good personality in the future.

Family is the main and first part of a child's development. Interaction in the family environment can shape a person into a very good person, and vice versa. The growth and mental development of a child since childhood is a family, so it is important for parents and the family environment to provide good family education to children.

According to Sumadi Suryabrata, since a human being was born into the world, he has made educational efforts, even though in a simple way. ${ }^{21}$ Thus, parents should be able to provide optimal and good education from the beginning and as early as possible, so that one day the next generation will be intelligent, skilled and virtuous. The family has a crucial impact, because early education and early understanding can be cultivated in the family. A tolerant family tends to give

${ }^{21}$ Sumadi Suryabrata, Psikologi Pendidikan, (Jakarta: Rajagrafindo Persada, 2007), hlm. 1-2. 
IJIERM: Vol. 2 No. 2 May - July 2020

birth to family members who are tolerant and can socialize well. This is quite important to provide a basis for tolerance in a multicultural society.

Family education is needed to teach children to have an open mind and be interested in understanding the differences. Families must avoid forcing children to be tolerant. Parents must condition the family in various accustomed situations and without making judgments. So children can learn to understand differences and learn to be tolerant without having to force it.

The diversity of Indonesia is a gift given by Allah SWT. We are obliged to continue to maintain and manage diversity within the framework of unity. Even in the midst of different races, tribes, languages and customs, we as fellow citizens can grow according to a balanced ecosystem. Therefore, the fundamental values that exist in Pancasila must be able to affirm the commitment to unity as one nation, so that diversity is not considered as an obstacle to the nation's progress.

Cultivating the value of tolerance in humans should have been done from an early age. The family is the most strategic place in educating these values and norms. Tolerant according to Siagian means taking on each other even though the job is not liked even though both parties disagree.22 This shows a condition of willingness to accept the reality of differences in other people around him. Parents can also apply and teach the attitudes of the Prophet Muhammad as uswatun hasanah to their children. The attitude of tolerance exemplified by the Messenger of Allah towards both Muslims and infidels without any social discrimination.

The rise of the phenomenon of intolerance that has occurred in Indonesia lately needs to be a joint reflection. Indonesia as a multicultural nation should jointly build unity and integrity as fellow citizens (ukhuwah wathoniyah). The danger of intolerance that increasingly threatens the integration of the nation, thus family education becomes a capital of strength in countering these concerns. As Muslims, family education needs to instill the value of tolerance through the example of the tolerant Prophet Muhammad.

Based on this discussion, family education has positive implications in order to ward off the dangers of intolerance that currently occur in Indonesia.

1. Islam prohibits coercion in religion. Muslims should strengthen their understanding and appreciation of aqidah and worship in order to produce a

22 SH Siagian, Agama-Agama di Indonesia, Semarang: Satya Wacana 1993, 115. 
generation of akblaqul karimah. Educational activities are continuously encouraged to develop the importance of the spirit of unity. Do not allow division and enmity between ethnic groups, religions and cultures of fellow Indonesians.

2. Cultivating pluralism in the family, plurality as sunnatullah so that there should be no claims of truth about differences, whether in ethnicity, language, race, and so on. Mutual respect and mutual cooperation between each other even in terms of differences in ethnicity, race, or religion, so it is not easy to be pitted against and swayed by the notions of intolerance or discrimination

3. Cultivate an attitude of inclusivism so that the next generation of the nation can avoid blind taqlid and narrow fanaticism. Violence and conflict in the name of religion is wrong. In addition, social-humanitarian problems, unemployment, poverty, and the moral crisis that befell this nation cannot be resolved only by giving importance to the ego of a particular ethnicity, race or religion.

\section{Conclusion}

Based on the results of the discussion and analysis that has been done, the authors draw the following conclusions:

1. Family is the main education received by every family member. A child as a family member is a sacred white paper, so the parents act as a pen, write down any attitudes that will make the child's character. Family education is very important in instilling noble values in the practice of daily life for their children. Therefore, the family education of the Muslim community is very good in preventing intolerance by educating the family from an early age.

2. The government as a policy maker is expected to be able to create laws that prohibit intolerant behavior, and accommodate and support tolerant behavior. The government is responsible for enforcing human rights regulations (HAM) and prohibiting and rejecting behavior that contains elements of hatred (hate crime) and discrimination against minorities, be it carried out by the government, community organizations and individuals.

3. Family education is important to teach children to have open insights. This is done to avoid the imposition of truth in a narrow sense, so that children can learn to understand the differences in social, religious and national life. 
IJIERM: Vol. 2 No. 2 May - July 2020

\section{References}

Abdullah, M. Imron. Pendidikan Keluarga Bagi Anak. Cirebon: Lektur, 2003.

Amirin, Tatang M. Menyusun Rencana Penelitian. Jakarta: RajaGrafindo Persada, 1995.

Anis, Muh. Sukses Mendidik Anak: Perspektif Al-Qur'an dan Hadis. Yogyakarta: Pustaka Insan Madani, 2009.

Arif, Syaiful. Islam, Pancasila, dan Deradikalisasi. Jakarta: PT Elex Media Komputindo, 2018.

Casram. Membangun Sikap Toleransi Beragama dalam Masyarakat Plural. Wawasan: Jurnal Ilmiah Agama dan Sosial Budaya 1, 2 Juli 2016.

Creswell, J. W. Research Desaign: Qualitative, Quantitative, and Mixed Methods Aprroaches 3rd Edition. California: Sage Publication, 2014.

Faridah, Ika Fatmawati. Toleransi Antarumat Beragama Masyarakat Perumahan. Unnes: Jurnal Komunitas, 5 (1) 2013.

Fatmawati. Peran Keluarga Terbadap Pembentukan Kepribadian Islam Bagi Remaja. Jurnal RISALAH, Vol. 27, No. 1, Juni 2016.

Lubis, Ridwan. Sosiologi Agama; Memahami Perkembangan Agama dalam Interaksi Sosial. Jakarta: Prenadamedia Group, 2015.

Moleong, Lexy J. Metode Penelitian Kualitatif. Bandung: Remaja Rosda Karya, 1990.

M. Yunus, Firdaus. Konflik Agama di Indonesia; Problem dan Solusi Perpecahannya. Jurnal Substantia, Volume 16 Nomor 2, Okotber 2014.

M. Zainuddin dan M. In'am Esha (ed). Islam Moderat; Konsepsi, Interpretasi, dan Aksi. Malang: UIN-Maliki Press, 2016.

M. Gandaatmaja, dan J. Rahmat. Keluarga dan Masyarakat Modern. Bandung: Remaja Rosda Karya, 1989.

Nazir, Moh. Metode Penelitian. Bogor: Ghalia Indonesia, 2005.

Qaimi, Ali. Menggapai Langit Masa Depan Anak. Bogor: Cahaya, 2002.

Siagian, SH. Agama-Agama di Indonesia. Semarang: Satya Wacana 1993.

Sulaeman, M.I. Pendidikan dalam Keluarga. Bandung: Alfabeta, 1994.

Suryabrata, Sumadi. Psikologi Pendidikan. Jakarta: Rajagrafindo Persada, 2007.

V. Clarke, dan V. Braun. Using Thematic Analysis in Psychology. Qualitative Research in Psychology, 2006. 
Yunanto, Sri. Islam Moderat vs Islam Radikal; Dinamika Politik Islam Kontemporer. Yogyakarta: Media Pressindo, 2018.

Yusuf, Syamsu. Psikologi Perkembangan Anak dan Remaja. Bandung: PT Remaja Rosda Karya, 2011. 